\title{
The Impact of Consumer Animosity and Consumer Ethnocentrism on Intention to Purchase Foreign Products: The Case of Chinese Branded Household Appliances in Vietnam Market
}

\author{
Nguyen ThiHuong Giang, Nguyen Dinh Khoi \\ International University-Vietnam National University HCMC, Vietnam \\ ndkhoi3107@gmail.com
}

\begin{abstract}
Vietnam-China bilateral relationship has sharply declined due to the recent conflicts on both economic and political affairs. On top of that, the current controversial incident regarding the East Sea issue has constantly deteriorated the connection. At this critical time when the effects of consumers' attitude toward Chinese products could not be overlooked, the empirical study aims to investigate the impacts of Consumer Animosity and Consumer Ethnocentrism on Purchase Intention of Chinese branded merchandise with the mediating role of Consumer Judgment. Household appliance category is chosen because of the dominance of Chinese brands in Vietnam market. In addition to the assessment of Animosity effect on Purchase Intention, the research is designated to examine its antecedences, including Perceived Economic Hardship and Normative Influences as well as their influences on Animosity. Structural Equation Modeling was utilized to test the theoretical framework, analyzing the data from a sample of 349 consumers with diverse backgrounds. The results have demonstrated that only Perceived economic hardship manifest a significant impacts on Animosity. Meanwhile, Animosity and Ethnocentrism have negative relationships with both Chinese branded household appliances Judgment and Purchase Intention. Overall, the study provides specific discussion and recommendations for the Vietnam household appliances industry and at the same time points into various directions for further researches.
\end{abstract}

Keyword: Consumer behaviors, Consumer Animosity, Consumer Ethnocentrism, Economic hardship, Normative Influences, Vietnam

\section{Introduction}

In the contemporary society, international trade has become increasingly popular. Countless enterprises intend for oversea market expansion, in search of favorable opportunities for growth (Tragos, 1998). Thanks to the advance in technology and numerous recent free trade agreements, the geographical and cultural differences have been dramatically shortened (Marchant and Ward, 2003). The international trade creates considerable opportunities and challenges for multinational organizations. There are foreseeable benefits of a shift to a new market. Firstly, there is a substantial reduction in production cost. By applying standardized marketing strategies with minor adjustments or locating the manufacturing facilities at places where low labor costs are available, the company can enhance their products' competitiveness. Furthermore, exporting a product is vital when it has reached maturity or decline stage in its life cycle in the internal market (Jaffe and Nebenzahl, 2001). Turning to the other side of the argument, one greatest drawback known as free trade barrier is worthy to be mentioned. This hindrance could be divided into two main types: tariff and non-tariff barriers. While import tariffs have been reduced substantially, non-tariff barriers are inevitable and impossible to eliminate. In preceding consumer researches, animosity and ethnocentrism belongs to this group (Klein et al., 1998). Ethnocentrism can be defined as a tendency to buy domestic products and avoid buying foreign products whereas Animosity refers to emotional status in consumers toward a country of origin that lead to the denial of choosing that country's commodity.

For many decades and even centuries, China and Vietnam has had the bilateral relationship in international business. Vietnam imports a tremendous number of Chinese products for domestic distribution and usage. As a matter of facts, China remained Vietnamese largest trade partner. In the first ten months of 2013, Chinese import market reached 30.37billion of US dollar, which accounts for $28.5 \%$ of Vietnam's total import value of this year. In addition, Vietnamese trade deficit with China soared to 19.6 billion, increased continuously to 21.6 billion in November and peaked at 23.7 billion at the end of 2013 (Nguyen, 2014; General Statistic Office, 
2013). According to this article, Chinese products are absolutely attractive due to its competitive prices. Chinese primary commodities that frequently come to Vietnam are chemical products, labor-intensive goods such as clothing, toys, as well as household appliances. Nonetheless, not long ago has China made a declaration on the ownership of the East Sea, also known as South China Sea called by the government (Vietnamnet, 2014). In spite of the debate in controversy, it has provoked other countries which also share the sovereignty of and have benefits in the East Sea. Relevant countries have expressed their hatred toward China, including Vietnam (BBC, 2015). As a consequence, Vietnamese consumers have negative attitudes toward "Made in China" products, thus being reluctant to buy them (Phan, 2014). It can be seen that the disagreement over China's claims on the East Sea are the dominant source that intensify patriotic attitude and hostility toward China, thus resulting in the hesitation to purchase Chinese commodity. Having been mentioned above, these emotional factors are named as animosity and ethnocentrism respectively and have been adopted in earlier studies as a construct for predicting consumer behaviors in different circumstances (Klein et al., 1998; Ettenson and Klein, 2005; Shoham et al., 2006).

Within Vietnamese context, household appliances are chosen as an investigated product in this study. There are numerous reasons. First of all, this is an ordinary and fundamental range of necessities that is widely consumed in majority of households in Ho Chi Minh City. This reality enables us to conduct the survey on a larger scale and get much information from different perspectives. Moreover, China has been well-known for this category because of reasonable prices and acceptable quality. There are several currently available Chinese brands utensils in Vietnam market, such as Haier, Midea, TLC and many other unbranded one. In recent years before the incident, Chinese branded household apparatuses accounted for $40 \%$ of assortment displays in numerous electronic retailers in Vietnam. With that being said, Chinese manufacturers held a huge market shares in this division (Huong, 2014). In spite of their frequent usage, consumers truly concerns about the brand and origin of the household appliances, not only because of quality and price, but also due to the effect of the "Anti-China campaign". Under such circumstances, household appliances are indeed appropriate products for minimum response bias (Hong, 2008). Although a large body of researches on Animosity and Ethnocentrism has been conducted in many different contexts and countries, with different modifications, there remain various issues to be addressed in Vietnamese contexts. First of all, there are few papers on Vietnamese consumer behaviors toward purchasing Chinese merchandises and Vietnamese attitudes toward Chinese branded products. Secondly, due to the recent political and economic affairs between Vietnam and China, there is an urgent demand to administer this study as it proves to be beneficial for researchers and industry practitioners. For the above reason, it is necessary to analyze consumers' behaviors and attitudes at this moment, when the two countries' connection has become more intense.

\section{Research Model and Hypotheses}

Theoretical Background: From Huang et al's study (2010), two psychological theories is indispensable for the two antecedences of Animosity. Hence, the brief explanation is introduced as following:

- Social Identity Theory proposed the mental state of human beings in which they categorize themselves into the "in-group" and others in "out-group" (Turner, 1987). The social in-groups then define and demonstrate the traits of their distinctive identity and the appropriateness of their behaviors (Goar, 2007). By adjusting their acts accordingly, they can enhance their own image and selfesteem. To maintain their self-established group, they favor their groups, as well as reject the others (Hewstone et al., 2002; Verlegh, 2007).

- Realistic Group Conflicts Theory reported all individuals who considered themselves as in-group perceived that the out-group could threaten their survival (Levine and Campbell, 1972). These perceived harms obviously strengthen the "feeling of membership, common identity, solidarity and cohesiveness within a group" (Huang et al., 2010, p 913), and reinforce the negative bias to the others groups as a consequence (Correll and Park, 2005; Esses et al., 1998).

These two theories are appropriate to apply to the context of Vietnam as this country has witnessed several evidences identical to the statements. As a nation with high level of solidarity, Vietnamese people consider themselves as in-group. The perceived threat from China aggressive action has enhanced these attribute, and increased anger toward the country. 'Made in China' products has now been boycotted in Vietnamese 
markets as a result of these dreads. Therefore, these theories are proposed in order to identify the two predecessors of Animosity factor as well as Animosity itself.

Economic Hardship: Economic hardship factor has been defined as the perceived incapability to gain living basics, to meet financial obligations, to acquire growth in finances as a result of the reduction in expense or the increase in income, and to believe in a brighter future in term of financial affairs (Barrera et al., 2001). The combination of Social Identity Theory and Realistic Group Conflict Theory inferred that the threats from the outsiders reinforce the fear of suffering from financial deprivation of the "in-group" (Shek, 2003). Consequently, the natives in the group would in turn express their hatred toward any objects belonging to the country which cause the perceived threats to them (Grant, 1991; Schmitt et al., 2003). In Klein et al.'s renowned paper in 1998, the Chinese consumers refused to purchase Japanese products, remembering the dreadful memories of economic hardship caused by the Japanese occupation in the past. Under homogenous circumstances, the first hypothesis in this study is proposed:

H1: Economic hardship positively affects Vietnamese Consumer Animosity toward China.

Normative Influences: Normative influence has appeared in various preceding researches on wide ranges of consumers' behaviors (Cohen and Golden, 1972; Bearden et al., 1989; Huang et al., 2010). Deutsch and Gerard (1955) defined normative influence in term of "the motivation to blend in with a group's norms, characteristics and attributes" (Huang et al., 2010, p. 914). Alternative definition by Burnkrant and Cousineau (1975) indicated normative influences as the impulse to adjust one's behavior to meet his/her surrounding expectation. Consumer studies divided the concepts into two categories: value expressive and utilitarian influences. On the one hand, value expressive reflects individual's desire to improve their image and selfesteem by referring to a group and generate motivation to adopt a behavior of another because that behavior satisfies their surrounding references (Park and Lessig, 1977; Price et al., 1989). On the other hand, utilitarian influence indicates the attempt to conform to the reference group's standard so as to achieve reward and avoid punishment (Park and Lessig, 1977; Bearden and Etzel, 1982; Price et al., 1989). Briefly, external influences from the surrounding neighborhood can alter a person behaviors, either to enhance themselves or to evade discipline.

Thanks to the correlation to people's mind set, the well-established concept of Normative Influence has been employed in several consumers' studies as a construct to measure their behaviors, such as their judgment and evaluation (Kassarjian and Robertson, 1981) or their decision making process (Deutsch and Gerard, 1955). With respect to buying behaviors, there are evidences showing the linkage of conspicuous consumption (Schroeder, 1996), the style of purchasing behavior with an attempt to demonstrate wealth and high social status (Eastman et al., 1999; O'Cass and McEwen, 2004). In other words, consumers paid more attention to their relevant reference when making any purchasing decision. In addition, Realistic Group Conflicts Theory suggests that the threat from the outsiders enhances the identity and solidarity within the in-group and consequently, resulting in the hostility to outer group that is perceived as the root of the threat (Huang et al., 2010). Individuals' judgment, evaluation and actions are usually influenced by the group they belong to, in order to keep themselves away from socially unacceptable thinking and actions (Wooten and Reed, 2004). It is reasonable to perceive that normative influence strengthens the enmity and lead to the depreciation and refusal to purchase hostile country's product is applied for a better value in their fellow's sight. Based on the scientific reasoning, the second hypothesis is formulated:

H2: Normative Influence positively affects Vietnamese Consumer Animosity to China.

Animosity: Consumer animosity is an essential construct that was taken into consideration in measurement and prediction of consumer behaviors in numerous previous researches (Klein et al., 1998; Nijssen and Douglas, 2004; Riefler and Diamantopoulos, 2007). As our review of the academic literatures, most of them adopted Klein's prevalent definition of Animosity (1998, p.90), which is: "the remnant of antipathy related to previous ongoing political, military, economic or diplomatic events will cause a direct negative effect on consumers' purchase behavior in the international markets". Alternatively, another definition from Averill (1982, as cited by Abraham, 2013, p.2) quoted that: "Animosity is a strong emotion of dislike and hatred stemming from past or present military, political or economic aggression and actions either between nations or peoples that are perceived to be unjustifiable or as going against what is socially acceptable". 
Two scholars' definitions on animosity are considerably alike regarding to the primary meanings. Hence, animosity can be understood as people negative sentiments toward a country due to its aggressive manners in various aspects. Animosity consists of two main categories in accordance with the inducements. They are war animosity, which is the reaction to war provocative and impetuous activities, and economic animosity, which is likely to result from trade disagreement or economic dominance from another stronger country (Klein and Morris, 1996; Hinck et al., 2004). Notwithstanding that Russell and Russell (2006) have placed special emphasis on the restriction of animosity definition to the past crucial occurrences; progressing incidents can actually trigger animosity (Tabassi et al., 2012). Past researches on Country-of-Origin reported that consumers focused on the provenance of the products as an instrument to evaluate that product. In consumers' perception, reputation of the country's name could be much more reliable than impartial information on characteristic (Hong and Wyer, 1990). Furthermore, two psychological theories mentioned in previous sections should be examined. While Social Identity Theory indicates that people would support their in-group and be favorable of it to any other "out-group", Realistic Group Conflict Theory anticipates the fear of sufferings and losses caused by an out-group creating negative bias toward these aliens, and apparently prejudices is dominant in consumers' appraisal of their item rather than objective assessment (Sherif and Sherif, 1979). Likewise, the homogenous hostility results in the reluctance and rejection to redeem product from infiltrating nations (Njissen and Douglas, 2004). In consequence, animosity toward the foreign counterparts negatively influences product judgment and purchase intention (Ettenson and Klein, 2005; Shoham et al., 2006; Verlegh, 2007). Although Klein denied the negative effect of animosity on quality judgment (Klein et al., 1998; Klein, 2002), Shoham et al. (2006) found that this relationship exists. Therefore, this paper proposed the two following hypotheses:

H3: Vietnamese Consumer Animosity to China negatively affects Chinese Product Judgment.

H5: Vietnamese Consumer Animosity to China negatively affects Intention to Purchase China goods.

Ethnocentrism: Another distinct construct applies in this paper is Consumer Ethnocentrism, which has been presented widely in multiple marketing papers (Shimp and Sharma, 1987; Klein et al., 1998; Pecotich and Rosenthal, 2001; Balabanis and Diamnatopoulos, 2004). It is defined in psychological as well as in consumer behavioral method. An original definition of ethnocentrism is "the view of things in which one's own group is the center of everything, and all others are scaled and rated with reference to it" (Sumner, 1906, p. 13). Shimp and Sharma (1987, p.280-9) defined ethnocentrism with respect to consumer viewpoint, being "a belief held by consumers on the appropriateness and indeed morality of purchasing foreign-made products". Implication can be made that consumers would favor any cultures that are analogous to their own, whereas reject any that is conflicting to their own culture (Adorno et al., 1950). To measure consumer ethnocentrism, Consumer Ethnocentric Tendencies Scale (from now preferred as CETSCALE) are applied. CETSCALE has been used in several studies with different contexts, from China, Russia to Turkey and Czech Republic (Balabanis et al., 2001; Klein et al., 2006). Most findings are the inverse links of the CETSCALE score and consumers' behavior in foreign-made products, judgment, willingness or intention to purchase, for instance (Shimp and Sharma, 1987; Netemayer et al., 1991; Sharma et al., 1995). The higher the score, the more ethnocentric consumer would be, and the higher tendency they are averse to imported products (Shimp and Sharma, 1987).

Upon our review of previous academic literatures, in ethnocentric consumers' perspective, buying products manufactured in other countries causes harms to their own economy, and increase unemployment rate. Hence, they boycott these oversea products regardless of various advantageous features of such products (Shimp and Sharma, 1987; Sharma et al., 1995; Evanschitzky et al., 2008). Ethnocentrism is constantly a vital actor in consumer's assessment, albeit the unavailability in domestic substitution (Nijssen and Douglas, 2004). Further, Sharma et al. (1995) found out and documented in their studies a belief of ethnocentric consumers that the redemption of exotic commodity involves with morality. Therefore, the construct carries the intention not to purchase such objects. Consequently, the construct has a negative causal relationship with consumers' behaviors on the purchase and evaluation of foreign products, which is identical to the reflection of the CETSCALE score (Olsen et al., 1993; Marcoux et al., 1997; Shoham and Brenic, 2003). This is a solid theoretical foundation for two next hypotheses:

H4: Consumer Ethnocentrism negatively affects Chinese Product Judgment.

H6: Consumer Ethnocentrism negatively affects Intention to purchase Chinese products. 
The Distinction between consumer ethnocentrism and consumer animosity: Both of them are unique constructs and contain several differences. The essential point to mention is the context in which these construct can be applied. While Ethnocentrism can be applied in all country and culture, Animosity is contextspecific (Klein et al., 1998; Abraham, 2013). However, both constructs are relevant in Vietnam context, not only because of the patriotism that has long manifested in the Vietnamese, but also owing to Chinese government's unreasonable action that aroused hostility amongst the people. Through the review of earlier papers, this study figures out the inconsistent hypothesis and findings among different researches and scholars. The majority the animosity studies stated out that animosity would increase the level of ethnocentrism (Klein et al., 1998; Nijssen and Douglass, 2004). LeVine and Campbell (1972) said that the aggressive behaviors from another country would lead to negative attitude to objects related to that country, hence reinforcing ethnocentrism. Shankarmahesh (2006) also pointed out this relationship as "animosity might be generalized to consumer ethnocentrism. Nonetheless, other papers proposed and confirmed the inverse relationship, which indicates the impacts of Ethnocentrism on Animosity (Akdogan et al., 2012). Therefore, this research aims to examine whether the former hypothesis exist in Vietnamese context.

H7: Consumer Animosity to China positively affects Consumer Ethnocentrism

Product Judgment and Intention to purchase Chinese household Appliances: Product judgment regards to the attitude of consumers toward specific objects or products (Rezvani et al., 2012). When products are taken into account, the evaluation is influenced by both cognitive and affective perspectives. However, emotions often prevail over reasons and logics when it comes to purchasing behaviors. In other word, consumers' sentiments influence buying decision more significantly as emotions could lead to both mental and behavioral responses (Hansen, 2005). Animosity could result in foreign product underestimation as mentioned (Ettenson and Klein, 2005; Shoham et al., 2006). Purchase intention has received special attention in recent marketing studies. The simplest definition of "what we think we will buy" is from the paper by Park (2002). Purchase intention can also be defined as the "the decision to act or psychological action that shows the individual's behaviors according to the products" (Wang and Yang, 2008). Furthermore, purchase intention and attitude are not alike in that attitude is the evaluation of products while intention is the process of selfmotivation to perform the purchasing action of individual (Ramadania et al., 2014). Ramadania et al. (2014) has mentioned the essential relationship between product judgment, through consumer attitudes, and purchasing behaviors. If judgment has not have such vital role in the final step of purchasing and owning the product, marketers and scholars would not pay intensive attention to it (Javalgy et al., 2005). In spite of Fishbein et al.'s declaration that the attitude toward merchandise does not strongly affect the behavior to purchase them (Fishbein and Aizen., 1975), other researchers have proven the positive relationship, especially with foreign products (Javalgy et al., 2005). Mowen and Minor (2002) stated that the actual behavior consists of all other behavior "to own, use and dispense" the products (Ramadania et al., 2014). Therefore, spiritual influences such as judgment and feelings are assumed to affect the willingness to purchase, as well as the willingness to use and dispense a product. Previous researches on Animosity and Ethnocentrism has also established the relationship of the factors and Purchase intention, in which Product judgment play a role of a mediator (Klein et al., 1998; Nguyen et al., 2008; Huang et al., 2010). From the result of these studies, it is reasonable to propose the last hypothesis:

H8: Chinese Product Judgment positively affects Intention to Purchase Chinese Product.

\section{Methodology}

Instrument development: The proposed model of this study consists of 6 constructs, each of which was measured carefully by multiple items adopted from previous paper. Economic hardship factor was set up from particular terms in Barrera et al.'s study (2001). Normative Influences were adapted from Bearden et al. (1989). Consumer Ethnocentrism was constructed based on to the CETSCALE of Shrimp and Sharma (1987). Animosity was built according to the study of Klein et al. (1998) and Klein (2002). Lastly, Product Judgment and Purchase Intention were adapted from Klein et al. (1998), who credited Darling and Arnold (1988), Darling and Wood (1990), Wood and Darling (1993) and Han (1988) for using their questionnaire references. The questions are modified to be appropriate for Vietnamese context and examined by 20 consumers in a pilot test to detect weaknesses before the primary fieldwork. All questions are 5 point Likert-scale multiple choices, from strongly disagree to strongly agree. The questions were attached in the appendix. 
Research Model: The proposed research model is hypothetically developed as follow:

Figure 1: Proposed Model (Klein et al., 1998, Huang et al., 2010)

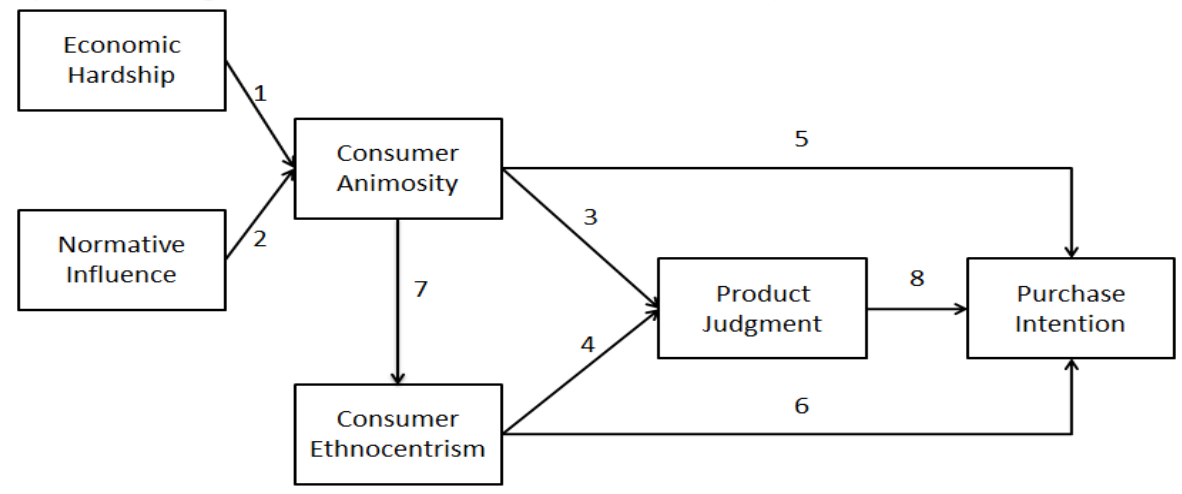

\section{Sampling and Data collection}

Consumers with following criteria will be investigated:

$>$ Consumer who is more than 18 years old.

$>$ Consumer who lives in Ho Chi Minh City for at least 3 years.

$>$ Consumer who has intention to purchase household products within 6 months

To specify the appropriate sample size, a formula designed by Tabachnick and Fidell (1996) is used to calculate the necessary number of respondents based on the number of items in the questionnaire. The formula is as follow: $\boldsymbol{Y}=\mathbf{8 X}+\mathbf{5 0}$

With $\mathrm{Y}$ as the necessary number of respondents and $\mathrm{X}$ as the number of items in the questionnaire. The questionnaire contains a total of 32 items. As in the formula, the appropriate target sample should be equal or more than 306. This study summarizes a 349-respondent sample.

Table 1: Sample profile

\begin{tabular}{lll}
\hline & Number & Percent \\
\hline Gender & & \\
Male & 136 & $39 \%$ \\
Female & 213 & $61 \%$ \\
Age & & \\
$18-24$ & 136 & $39 \%$ \\
$25-30$ & 117 & $33.5 \%$ \\
$31-45$ & 79 & $22.6 \%$ \\
$>45$ & 17 & $4.9 \%$ \\
Educational level & & \\
High school Level & 47 & $13.5 \%$ \\
College Level & 83 & $23.8 \%$ \\
Bachelor Level & 211 & $60.5 \%$ \\
Master/Doctor Level & 8 & $2.3 \%$ \\
Product & & \\
Experience & & \\
None & 128 & $36.7 \%$ \\
Few (1-3 products) & 153 & $43.8 \%$ \\
Many (more than 3) & 68 & $19.5 \%$ \\
\hline
\end{tabular}

In the respondent profile, there are 136 male and 213 female, which account for $39 \%$ and $61 \%$ respectively. As household appliances are ordinary products, there is no restriction on age beside the aforementioned criterion. There are four groups of age in this survey: 18-24, 25-30, 30-45, and more than 45. Explicitly, the range of $18-24$ seizes the highest percentage, $39 \%$, which is followed closely by $25-30$ categories, $33.5 \%$. In 
contrast, only one-fifth of the total consumers fall in the range 30-45. Most of our respondents lie in Bachelor level, with more than $60 \%$. College level comes in the second places with much lower percentage, $23 \%$. With respect to Chinese Household appliances product usage experience, respondents who have owned and used these products occupy a large proportion, approximately 63\%. On the other hands, individuals who have never owned a Chinese appliance are nearly one-third of the total respondents.

\section{Data Analysis and Finding}

Table 2: Cronbach's alpha value

\begin{tabular}{lll}
\hline Variable & Cronbach's alpha & Number of items \\
\hline Normative Influence & 0.735 & 5 \\
Economic Hardship & 0.890 & 6 \\
Animosity & 0.758 & 4 \\
Ethnocentrism & 0.795 & 6 \\
Product Judgment & 0.789 & 5 \\
Purchase Intention & 0.860 & 5 \\
\hline
\end{tabular}

Table 3: Exploratory Factor Analysis Pattern Matrix

\begin{tabular}{|c|c|c|c|c|c|c|}
\hline & $\begin{array}{l}\text { Factor } \\
1\end{array}$ & 2 & 3 & 4 & 5 & 6 \\
\hline H2 & .835 & & & & & \\
\hline H1 & .793 & & & & & \\
\hline H4 & .777 & & & & & \\
\hline H5 & .765 & & & & & \\
\hline H3 & .758 & & & & & \\
\hline H6 & .655 & & & & & \\
\hline PI2 & & .824 & & & & \\
\hline PI1 & & .783 & & & & \\
\hline PI4 & & .744 & & & & \\
\hline PI3 & & .722 & & & & \\
\hline PI5 & & .601 & & & & \\
\hline ЕTH3 & & & .725 & & & \\
\hline ETH5 & & & .698 & & & \\
\hline ETH2 & & & .683 & & & \\
\hline ETH1 & & & .595 & & & \\
\hline ETH4 & & & .568 & & & \\
\hline PJ2 & & & & .772 & & \\
\hline PJ1 & & & & .755 & & \\
\hline PJ3 & & & & .727 & & \\
\hline PJ4 & & & & .607 & & \\
\hline NI3 & & & & & .679 & \\
\hline NI4 & & & & & .633 & \\
\hline NI1 & & & & & .566 & \\
\hline NI2 & & & & & .562 & \\
\hline NI5 & & & & & .558 & \\
\hline A5 & & & & & & .778 \\
\hline A2 & & & & & & .654 \\
\hline A3 & & & & & & .649 \\
\hline A4 & & & & & & .570 \\
\hline
\end{tabular}


This study applies four procedural tests, utilizing 2 statistical computer softwares, SPSS 20 and AMOS 20. First of all, the reliability of the data set is tested and the exploratory factor analysis is run to examine the factor classification of the data. After that, confirmatory factor analysis (CFA) is used for validity and model fitness testing and lastly, structural equation modeling (SEM) is utilized to test the proposed hypotheses. In the reliability test, alpha value must be higher than 0.7 , showing the internal consistency of the data (Table 2). In the Exploratory factor analysis, item loadings should be higher than 0.5. Items with either low loadings or cross loadings are required to be removed. In this study, the deleted items are PJ5 and ETH6 (Table 3). For the next step, confirmatory factor analysis is applied with an attempt to test the reliability and validity of the data. The usually tested validity consists of Convergent Validity and Discriminant Validity. While convergent validity indicates how each items represent for its factor, Discriminant Validity demonstrate the distinctiveness between the each factors. Table 4 demonstrates the standardized factor loadings, Average Variance Extracted (AVE), and Composite Reliability (CR) of the factors, which are the statistical requirement for Convergent validity. Although Bagozzi and Yi (1988) suggested that CR must be higher than 0.7 and AVE must be higher than 0.5 so that convergent validity can be achieved, Fornell and Larcker (1981) shown evidence that if AVE is less than 0.5 and the composite reliability is higher than 0.6 , convergent validity of the construct is still assured. Noticeably, that data meets the requirements of the convergent validity test (Table 4). With regard to discriminant validity, the same author proposed the square root of AVE should be larger than the its correlation coefficients with other factor (Fornell and Larcker, 1981), and this validity is also accomplished (Table 5). For the model fitness, it is obvious that all imperative threshold is satisfied (Table 6). Structural Equation Modeling confirms that all hypotheses are approved, except for the hypothesis H2, between Normative Influences and Animosity (Table 7).

Table 4: Convergent Validity-CFA

\begin{tabular}{lllll}
\hline Factor & Items & Item loadings & AVE & CR \\
\hline Economic Hardship & H1 & .725 & 0.565 & 0.886 \\
& H2 & .757 & & \\
H3 & .792 & & \\
H4 & .785 & & \\
Normative Influence & H5 & .792 & & \\
& H6 & .649 & .432 & .690 \\
Animosity & N3 & .640 & & \\
Ethnocentrism & N4 & .779 & & \\
& N5 & .529 & .615 & .741 \\
Product Judgment & A4 & .994 & & \\
& A5 & .491 & .521 & .765 \\
ETH3 & .752 & & \\
ETrchase Intention & ETH4 & .759 & .507 & .804 \\
& ETH5 & .650 & & \\
& PJ1 & .795 & & \\
& PJ2 & .726 & .607 & .859 \\
& PJ3 & .688 & & \\
& PJ4 & .630 & & \\
\hline
\end{tabular}


Table 5: Discriminant Validity-CFA

\begin{tabular}{llllll}
\hline NI & H & PI & ETH & PJ & A \\
\hline 0.657 & & & & & \\
-0.050 & 0.752 & & & & \\
-0.057 & -0.198 & 0.779 & & & \\
0.083 & 0.191 & -0.444 & 0.722 & & \\
0.144 & 0.128 & 0.328 & -0.250 & 0.712 & \\
0.026 & 0.211 & -0.426 & 0.325 & -0.285 & 0.784 \\
\hline
\end{tabular}

Table 6: Model fitness-CFA

\begin{tabular}{llllll}
\hline & CMIN/df & GFI & TLI & CFI & RMSEA \\
\hline Criterion & $<2$ & $>0.9$ & $>0.9$ & $>0.9$ & $<0.05$ \\
Score & 1.841 & 0.902 & 0.937 & 0.938 & 0.049 \\
\hline
\end{tabular}

Table 7: Hypothesis testing-SEM

\begin{tabular}{lll}
\hline Hypothesis & p-value & Structural Equation Modeling \\
\hline H1: Economic hardship -> Animosity & $.005^{* *}$ & Supported \\
H2: Normative Influences -> Animosity & .516 & Not Supported \\
H3: Animosity -> Product judgment & $.003^{* *}$ & Supported \\
H4: Ethnocentrism -> Product Judgment & $.017^{*}$ & Supported \\
H5: Animosity -> Purchase Intention & $* * *$ & Supported \\
H6: Ethnocentrism -> Purchase Intention & $* * *$ & Supported \\
H7: Animosity -> Ethnocentrism & $* * *$ & Supported \\
H8: Product judgment -> Purchase & $.006^{* *}$ & Supported \\
Intention & & \\
\hline
\end{tabular}

Discussion: First of all, among the two independent antecedences of Animosity, only Economic Hardship has significant impact. The situation is identical to Huang et al. (2010). Given some recent development, Vietnam is still a developing country at the moment. Obviously, the perceived hardship exists in Vietnamese people' minds. This threat of financial deprivation is strengthened as people believed that China and its action are the cause. This is the reason why hypothesis H1"Economic hardship positively affects Vietnamese Consumer Animosity toward China" is approved with a very good significant value. In contrast, Normative Influences do not have considerable impacts like Economic hardship. In Vietnamese situation, people do pay attention to surrounding public eyes, but to some extent only. Regarding to the feeling toward China and the purchasing behavior of Chinese products, reference groups have marginal effects. Meanwhile, all other hypotheses from the original models of Klein et al. in 1998 with two added hypotheses adapted from later literature are all supported. The results are similar to that of previous researchers (Witkowski, 2000; Klein, 2002; Nijssen and Douglas, 2004).

Both hypotheses H3-"Vietnamese Consumer Animosity to China negatively affects Chinese Product Judgment" andH4 - "Consumer Ethnocentrism negatively affects Chinese Product Judgment" are well supported. This indicates that both antipathy toward China and the feeling of Ethnocentrism affect the assessment of Chinese products. Two constructs affect differently, but both result in Chinese product underestimation. While animosity leads to the depreciation of objects related to its sources, ethnocentric consumers value domestic products much more than foreign countries' one. Remarkably, the hypothesis that is denied in paper of Klein et al. (1998), H3, is justified in this study. This current result is identical to Shoham et al.'s study in 2006, previously mentioned in the review of literature. Likewise, hypotheses H5-"Vietnamese Consumer Animosity to China negatively affects Intention to Purchase China goods" and H6 - "Consumer Ethnocentrism negatively affects Intention to purchase Chinese products" are substantiated by their significant values, indicating the direct negative relationship of Animosity and Ethnocentrism on intention to purchase Chinese products. In other words, these two psychological factors play a crucial and dominant role in Vietnamese consumers' intention when it comes to purchasing Chinese household appliances. 
The hypothesis H7- "Consumer Animosity to China positively affects Consumer Ethnocentrism" is robustly supported. The feeling of antipathy could be generalized into ethnocentrism. Vietnamese consumers who express their hatred toward China due to the political and economic issues will reject Chinese household appliances and use Vietnamese products instead. This served as a brief explanation for this hypothesis. Lastly, hypothesis H8 - "Chinese Product Judgment positively affects Intention to Purchase Chinese Product" is confirmed as significant. Clearly, the judgment of one product is positively related to the intention to buy and own them. The better the judgment is, the higher the intention would be.

\section{Recommendation and Direction for Further Study}

For Chinese Electronic Household appliances suppliers: In other to operate in Vietnam market, Chinese organization should realize the high level of Animosity in Vietnamese consumers. Animosity is considered to be a threat to an international firm originating from a country that has controversial issue in political, economic or military aspects with the export nation. With appropriate recognition on the current affair, marketing managers are required to develop master plans to deal with this potential hazard. The primary strategy is to arrange an in-depth marketing research to measure the negative bias. In the recommended study, demographics and geographic information should be included as the perception of hostility may vary among different backgrounds and regions. For example, people in rural and urban areas may have diverse viewpoints regarding attitudes toward China and purchasing behaviors of its products. With detailed statistics, they can tailor their strategies to reduce such impacts and thus increase market shares and profits. When it comes to animosity and ethnocentrism, ordinary techniques of marketing such as advertisement and promotion may become ineffective. Marketers could consider the following thoughtful insights given by this research or relevant studies.

The first scheme is to directly address the animosity issues. The combination of intensive public relation and communication instruments is indispensable in the attempt to change consumers' perception and prejudice. The communication campaign should emphasize that the products and the brand does not involved with the current incident. Since the diplomatic issues are recent, the strategy could become even more advantageous (Klein et al., 1998). In addition, the effects of Economic Hardship on Animosity should not be overlooked. Perceived deprivation transforms into Animosity toward China as Vietnamese citizens believe that China is a prime inducement of East Sea's instability. Manufacturers could use the similar method to inform consumers that using Chinese electronic household appliances generates no detrimental impacts to Vietnamese economy and society. Doing so, manufacturers can also reduce the negative sentiments of Chinese products in ethnocentric consumers. Additional fruitful approach embraces Chinese manufacturer's facility relocation to and manufacture household appliances in Vietnam. The process enables the producer to create hybrid products, which provides marketers with the flexibility in coping with the influences of consumer animosity related to product origin (Levin and Jasper, 1996). In fact, many Chinese household appliances suppliers have invested their own manufactory in Vietnam. However, their promoting activities do not take advantages of this reality. The brand name could be altered by placing the term "made in Vietnam". Consequently, the company can utilize consumer Ethnocentrism to gain more sales and capture more market shares while minimizing preconception from hostile users. Last but not least, segmentation of target consumers into groups with distinctive attributes that do not strongly harbor antipathy is one essential step. Although the majority of Vietnamese consumers hold hostility toward China, the level of animosity actually differs. Therefore, spotting out a group of consumers whose levels of animosity are not high enough for them to abandon Chinese appliances and adjust marketing strategies to meet their desires is another plausible strategy that should be taken into consideration.

For Vietnamese Electronic Household Appliance Manufacturers: For local marketing managers, this study gives suggestions on brand positioning strategies. As Ethnocentrism can be transferred into negative bias toward foreign products, this can be utilized as a "powerful weapon" to fight in the arena where international trade continuously increases. Vietnamese products quality is incomparable to those of developed countries in consumers' mindset (Nguyen \& Nguyen, 2004). Thus, instead of focusing only on product attributes, a strategy that emphasizes ethnocentric attitudes in purchasing the product shines. Local managers should take advantages of ethnocentrism to increase market shares and profit. "Buy Vietnamese" is a very suitable strategy to be used. 
For Vietnamese retailers: Most of the electronic household appliances reach consumers through intermediary retailers. Therefore, the findings of this study are beneficial to the retailer practitioners. Being aware of the effects of Animosity on consumers, the mangers should carefully consider whether to import Chinese branded household appliances and to put it on assortment display. If the necessity of importing Chinese branded products is in place, the brand names and the suppliers should be taken into thorough consideration. The retailers should choose hybrid appliances that are manufactured in Vietnam in order to utilize consumer's Ethnocentrism while minimizing the impacts of Animosity. They can implement some previously mentioned strategies to promote their products in cooperation with the manufacturers. Chinese branded appliances has a big advantage on price and an acceptable quality, which they should emphasize on their advertising. In addition, they should highlight that the products is manufactured in Vietnam, therefore deemphasizing the brand real origin as well as triggering ethnocentric belief. If the demand for Chinese branded household products is not high, the retailers should choose Vietnamese brands for the above reason. Ethnocentrism could be exploited to enhance sales and profit.

Theoretical Implication: The study confirms the Animosity model for foreign product purchase in a context when there are recent controversial issues. While preceding research concentrates on past events as a source of Animosity, this paper proves that progressing events can still trigger Animosity. Animosity and Ethnocentrism affects purchase intention directly and indirectly, through Product Judgment. Moreover, a hypothesis between Animosity and Product Judgment, earlier denied by Klein et al. (1998), is justified in this study. This research also investigates the antecedences of Animosity, which previous papers lack. The findings can contribute humbly to the academic field of Animosity and Consumer behaviors.

Suggestion for Further Study: Although the research put best effort in covering all aspects regarding to Animosity model, there are some limitations which are needed to be clarified. Further study should consider these drawbacks to have a fuller understanding of Animosity in Vietnamese context. Firstly, it is administered within Ho Chi Minh City only. As a result, its finding can only be applied to Ho Chi Minh City. There are many differences among distinctive regions. For instance, there are enormous distances in consumer behaviors between the rural and the urban area. To fully understand the effect of Animosity and Ethnocentrism to purchase intention in Vietnam, multi-regional research should be carried out. Secondly, the research is centered on Chinese branded household appliances. Other researches could try a new category of products to see if the findings differ. Thirdly, the research finds no relationship between Normative Influences and Animosity. Nonetheless, this study infers that Vietnam possess a collectivism culture. Thus, this research suggests further researches should spend times on design a better set of questionnaires and pretest the model to see if the proposed hypothesis really exist. Lastly, the research exercises only in quantitative method. The results might not be interesting enough. However, due to the shortage of time, labor and budget, qualitative research cannot be implemented. Later study can conduct qualitative methods (focus group and in-depth interview, to name a few) to contribute more attractive findings.

\section{Appendix:}

\section{Economic Hardship:}

The family standard of living is reduced over the coming 3 months.

My family suffers from difficulty in paying different spending household bills.

I feel I have to reduce the money spent on clothing over the coming three months.

I feel I have to reduce the money spent on food over the coming 3 months.

I have less money leftover at the end of the months in the coming 3 months.

I have to add another job to make end meets.

\section{Normative Influence:}

It is important that others like the products (and brands) I buy
I like to know what products (and brands) make good impressions on others.

I achieve a sense of belonging to the society by purchasing the same products (and brands) they purchase.

I often feel identical with other people by purchasing the same products (and brands) they purchase.

When buying products, I generally purchase those brands that I think others will approve of.

\section{Consumer Animosity:}

My attitude toward China is

I feel angry toward China because of national issues (the East sea issue and the other economic issues)

In general, the Chinese is doing business unfairly with Vietnam. China is not a reliable trading partner. 
I cannot forgive China for placing the oil rig in Vietnam territory as well as attacking Vietnamese fishermen and navy soldiers.

\section{Consumer Ethnocentrism:}

Vietnamese products, first, last, and foremost. A real Vietnamese should buy Vietnamese products. Buying foreign products is not a correct activity for Vietnamese.

Buying foreign products damages local businesses. We should purchase products manufactured in Vietnam instead of letting other countries get rich off of us.

We should buy from foreign countries if and only if those products that we cannot obtain within our own country.

Chinese Branded Product Judgment:

Chinese household appliances are carefully produced and have fine workmanship
Chinese household appliances made in China are generally of a higher quality than similar products available from other countries

Chinese Household appliances show a very high degree of technological advancement

Chinese household appliances usually show a very clever use of color and design.

Chinese household appliances are usually a good value for the money.

Chinese Branded Product Purchase Intention:

If buying a household appliance, I will not buy a Chinese one.

Whenever possible, I avoid buying Chinese household appliances.

I would feel uncomfortable if I bought a Chinese household appliance.

I do not like the ideas of owning Chinese household appliances.

If two appliances were equal in quality, but one was from other countries and one was from China, I would pay for the product not from China.

\section{Reference}

Abraham, V. (2013). Does consumer animosity impact purchase involvement? An empirical investigation. International Journal of Business and Social Science, 4(1), 1-11.

Adorno, T. W., Frenkel-Brunswik, E., Levinson, D. J. \& Sanford, R. N. (1950). The authoritarian personality.

Akdogan, M. S., Ozgener, S., Kaplan, M. \& Coskun, A. (2012). The effects of consumer ethnocentrism and consumer animosity on the re-purchase intent: The moderating role of consumer loyalty. EMAJ: Emerging Markets Journal, 2(1), 1-12

Averill, J. (1982). Anger and aggression: An essay on emotion. New York: Springer-Verlag

Bagozzi, R. P. \& Yi, Y. (1988). On the evaluation of structural equation models. Journal of the academy of marketing science, 16(1), 74-94.

Balabanis, G. \& Diamantopoulos, A. (2004). Domestic country bias, country-of-origin effects, and consumer ethnocentrism: a multidimensional unfolding approach. Journal of the Academy of Marketing Science, 32(1), 80-95.

Balabanis, G., Diamantopoulos, A., Mueller, R. D. \& Melewar, T. C. (2001).The impact of nationalism, patriotism, and internationalism on consumer ethnocentric tendencies. Journal of International Business Studies, 32(1), 157-175.

Barrera, M., Caples, H. \& Tein, J. Y. (2001). The psychological sense of economic hardship: Measurement models, validity, and cross-ethnic equivalence for urban families. American journal of community psychology, 29(3), 493-517.

BBC. (2015). Bbccom. Retrieved Jan, 2015, from http://www.bbc.com/news/world-asia-pacific 13748349.

Bearden, W. O. \& Etzel, M. J. (1982). Reference group influence on product and brand purchase decisions. Journal of consumer research, 3, 183-194.

Bearden, W. O., Netemeyer, R. G. \& Teel, J. E. (1989). Measurement of consumer susceptibility to interpersonal influence. Journal of consumer research, 2, 473-481.

Burnkrant, R. E. \& Cousineau, A. (1975). Informational and normative social influence in buyer behavior. Journal of Consumer research, 3, 206-215.

Cohen, J. B. \& Golden, E. (1972). Informational social influence and product evaluation. Journal of applied Psychology, 56(1), 54-59.

Correll, J. \& Park, B. (2005). A model of the in-group as a social resource. Personality and Social Psychology Review, 9(4), 341-359. 
Darling, J. R. \& Arnold, D. R. (1988). The competitive position abroad of products and marketing practices of the United States, Japan, and selected European countries. Journal of Consumer Marketing, 5(4), 6168.

Darling, J. R. \& Wood, V. R. (1990). A longitudinal study comparing perceptions of US and Japanese consumer products in a third/neutral country: Finland 1975 to 1985. Journal of International Business Studies, 21(3), 427-450.

Deutsch, M. \& Gerard, H. B. (1955). A study of normative and informational social influences upon individual judgment. The journal of abnormal and social psychology, 51(3), 629-636.

Eastman, J. K., Goldsmith, R. E. \& Flynn, L. R. (1999). Status consumption in consumer behavior: Scale development and validation. Journal of Marketing Theory and Practice, 7(3), 41-52.

Esses, V. M., Jackson, L. M. \& Armstrong, T. L. (1998). Intergroup competition and attitudes toward immigrants and immigration: An instrumental model of group conflict. Journal of Social Issues, 54(4), 699-724.

Ettenson, R. \& Klein, J. G. (2005). The fall-out from French nuclear testing in the South Pacific: a longitudinal study of consumer boycotts. International Marketing Review, 22(2), 199-224.

Evanschitzky, H., Wangenheim, F. V., Woisetschläger, D. \& Blut, M. (2008).Consumer ethnocentrism in the German market. International Marketing Review, 25(1), 7-32.

Fishbein, M. \& Ajzen, I. (1975). Belief attitude, intention, and behavior: An introduction to theory and research. Reading, MA: Addison-Wesley.

Fornell, C. \& Larcker, D. F. (1981). Evaluating structural equation models with unobservable variables and measurement error. Journal of Marketing Research, 18(1), 39-50.

General statistic office. (2013). Tap chi Tai chinh. Retrieved Oct, 2014, from http://tapchitaichinh.vn/baocao-va-thong-ke-tai-chinh/tinh-hinh-xuat-nhap-khau-nam-2013-39079.html

Goar, C. D. (2007). Social identity theory and the reduction of inequality: Can cross-cutting categorization reduce inequality in mixed-race groups? Social Behavior and Personality: an international journal, 35(4), 537-550.

Grant, P. R. (1991). Ethnocentrism between groups of unequal power under threat in intergroup competition. The Journal of social psychology, 131(1), 21-28.

Han, C. M. (1988). The Role of Consumer Patriotism in the Choice of Domestic versus Foreign Products. Journal of Advertising Research, 28, 25-31

Hansen, T. (2005). Consumer adoption of online grocery buying: a discriminant analysis. International Journal of Retail \& Distribution Management, 33(2), 101-121.

Hewstone, M., Rubin, M. \& Willis, H. (2002). Intergroup bias. Annual review of psychology, 53(1), 575-604.

Hinck, W., Cortes, A. \& James, K. (2004). An empirical investigation of the failure of Eastern German products in Western German markets. Journal for International Business and Entrepreneurship Development, 2(1), 104-111.

Hong, S. T. \& Wyer Jr, R. S. (1990). Determinants of product evaluation: Effects of the time interval between knowledge of a product's country of origin and information about its specific attributes. Journal of Consumer Research, 17(3), 277-288.

Hong, Z. (2008). Animosity or Preference, Chinese Consumers' Attitudes towards Japanese Products (Doctoral dissertation).

Huang, Y. A., Phau, I. \& Lin, C. (2010). Consumer animosity, economic hardship, and normative influence: How do they affect consumers' purchase intention? European Journal of Marketing, 44(7/8), 909-937.

Huong, K. (2014). Báo Đồng Nai. Retrieved Sept, 2014, from http://www.baodongnai.com.vn/kinhte/201408/hang-dien-may-trung-quoc-that-the-2329870/

Jaffe, E. D. \& Nebenzahl, I. D. (2001). National Image \& Competitive Advantage: The Theory and Practice of Country-of-Origin Effect, Copenhagen Business School Press

Javalgy, R. G., Khare, V. P., Gross, A. C. \& Scherer, R. F. (2005). An application of the consumer ethnocentrism model to French consumers. International Business Review, 14(3), 325-344.

Kassarjian, H. H. \& Thomas, S. R. (1981). Social Processes. Perspectives in Consumer Behavior, Glen-view, IL: Scott, Foresman, 317-328.

Klein, J. G. (2002). Us versus them, or us versus everyone? Delineating consumer aversion to foreign goods. Journal of International Business Studies, 2, 345-363. 
Klein, J. G., Ettenson, R. \& Morris, M. D. (1998). The animosity model of foreign product purchase: An empirical test in the People's Republic of China. The Journal of Marketing, 2, 89-100.

Klein, J. G., Ettenson, R. \& Krishnan, B. C. (2006). Extending the construct of consumer ethnocentrism: When foreign products are preferred. International Marketing Review, 23(3), 304-321.

Klein, J. G. \& Morris, M. D. (1996). In Klein, Jill G., Ettenson, Richard (1999). Consumer animosity and consumer ethnocentrism: An analysis of unique antecedent. Journal of International Consumer Marketing, 11, 5 - 24.

Levin, I. P. \& Jasper, J. D. (1996). Experimental analysis of nationalistic tendencies in consumer decision processes: Case of the multinational product. Journal of Experimental Psychology: Applied, 2(1), 17-30.

Levine, R. A. \& Campbell, D.T. (1972). Ethnocentrism: Theories of Conflict, Ethnic Attitudes, and Group Behavior, Wiley, New York, NY.

Marchant, C. \& Ward, S. (2003). At home or abroad: An examination of expatriate and cross-national differences in the use of country of origin information. Journal of Asia Pacific Marketing, 2(1), 12-43.

Marcoux, J. S., Filiatrault, P. \& Cheron, E. (1997). The attitudes underlying preferences of young urban educated Polish consumers towards products made in western countries. Journal of International Consumer Marketing, 9(4), 5-29.

Mowen, J. C. \& Minor, M. (2002). Consumer behavior Upper Saddle River: Pretience Hall.

Netemeyer, R. G., Durvasula, S. \& Lichtenstein, D. R. (1991). A cross-national assessment of the reliability and validity of the CETSCALE. Journal of Marketing Research, 3, 320-327.

Nguyen, T. D. \& Nguyen, T. T. M. (2004). Key Factors Affecting the Choice of Foreign and Local Products by Vietnamese Consumers, Research Report, Grant No. B2004-22-65, Vietnam's Ministry of Education and Training: Ho Chi Minh City

Nguyen, T. D., Nguyen, T. \& Barrett, N. J. (2008). Consumer ethnocentrism, cultural sensitivity, and intention to purchase local products-evidence from Vietnam. Journal of consumer behavior, 7(1), 88-100.

Nguyen, T. D. (2014). Baodatvietvn. Retrieved from http://baodatviet.vn/kinh-te/thi-truong/thoi-xau-cuanguoi-viet-khien-hang-trung-quoc-ngap-thi-truong-2364289/

Nijssen, E. J. \& Douglas, S. P. (2004). Examining the animosity model in a country with a high level of foreign trade. International Journal of Research in Marketing, 21(1), 23-38.

O'cass, A. \& McEwen, H. (2004). Exploring consumer status and conspicuous consumption. Journal of Consumer Behavior, 4(1), 25-39.

Olsen, J. E., Biswas, A. \& Granzin, K. L. (1993). Influencing consumers' selection of domestic versus imported products: Implications for marketing based on a model of helping behavior. Journal of the Academy of Marketing Science, 21(4), 307-321.

Park, C. (2002). A model on the online buying intention with consumer characteristics and product type. In Proceedings of Ausweb, The Eighth Australian World Wide Web Conference, Queensland, Australia.

Park, C. W. \& Lessig, V. P. (1977). Students and housewives: Differences in susceptibility to reference group influence. Journal of consumer Research, 2, 102-110.

Pecotich, A. \& Rosenthal, M. J. (2001). Country of origin, quality, brand, and consumer ethnocentrism. Journal of Global Marketing, 15(2), 31-60.

Phan. (2014). Dantri. Retrieved Sept, 2014, from http://dantri.com.vn/suc-manh-so/cang-thang-leo-thangdien-thoai-trung-quoc-kho-song-tai-viet-nam-872401.htm.

Price, L. L., Feick, L. F. \& Higie, R. A. (1989). Preference heterogeneity and co-orientation as determinants of referent influence in the choice of service providers. Journal of Business Research, 19, 227-242.

Ramadania, R., Gunawan, S. \& Jamaliah, J. (2014). Country of Origin Effect and Animosity on The Attitude and Purchase Intention of Foreign Products. Asean Marketing Journal, 5(1), 59-68.

Rezvani, S., Dehkordi, G. J., Rahman, M. S., Fouladivanda, F., Habibi, M. \& Eghtebasi, S. (2012). A conceptual study on the country of origin effect on consumer purchase intention. Asian Social Science, 8(12), 205.

Riefler, P. \& Diamantopoulos, A. (2007), Consumer animosity: a literature review and a reconsideration of its measurement. International Marketing Review, 24(1), 87-119.

Russell, D. W. \& Russell, C. A. (2006). Explicit and implicit catalysts of consumer resistance: The effects of animosity, cultural salience and country-of-origin on subsequent choice. International Journal of Research in Marketing, 23(3), 321-331.

Schmitt, M. T., Branscombe, N. R. \& Kappen, D. M. (2003). Attitudes toward group-based inequality: Social dominance or social identity? British Journal of Social Psychology, 42(2), 161-186. 
Schroeder, J. E. (1996). An analysis of the consumer susceptibility to interpersonal influence scale. Journal of Social Behavior and Personality, 11(3), 585-599.

Shankarmahesh, M. N. (2006). Consumer ethnocentrism: an integrative review of its antecedents and consequences. International Marketing Review, 23(2), 146-172.

Sharma, S., Terence, A. S. \& Jeongshin, S. (1995). Consumer Ethnocentrism: A Test of Antecedents and Moderators. Journal of Academy of Marketing Science, 23(1), 26-37.

Shek, D. T. (2003). Economic stress, psychological well-being and problem behavior in Chinese adolescents with economic disadvantage. Journal of Youth and Adolescence, 32(4), 259-266.

Sherif, M. \& Sherif, C. W. (1979). Research on intergroup relations. The social psychology of intergroup relations, 1, 7-18.

Shimp, T. A. \& Sharma, S. (1987). Consumer ethnocentrism: construction and validation of the CETSCALE. Journal of marketing research, 4, 280-289.

Shoham, A. \& Brenčič, M. M. (2003). Consumer ethnocentrism, attitudes, and purchase behavior: An Israeli study. Journal of International Consumer Marketing, 15(4), 67-86.

Shoham, A., Davidow, M., Klein, J. G. \& Ruvio, A. (2006). Animosity on the home front: The Intifada in Israel and its impact on consumer behavior. Journal of International Marketing, 14(3), 92-114.

Summer, W. G. (1906). Folkways: The Sociological Importance of Usages, Manners, Customs, Mores, and Morals. Ginn \& Co.: New York.

Tabachnick, B. G. \& Fidell, L. S. (1996). Using Multivariate Statistics, Third Ed. New York: Harper Collins.

Tabassi, S., Esmaeilzadeh, P. \& Sambasivan, M. (2012). The role of animosity, religiosity and ethnocentrism on consumer purchase intention: A study in Malaysia toward European brands. African Journal of Business Management, 6(23), 6890-6902.

Tragos, W. G. (1998). International Branding. I hart, Susannahoch John Murphy (red.). 1998. Brands: The New Wealth Creators. London: MacMillan Press

Turner, J. C. (1987). A self-categorization theory, in Hogg, M., Oakes, P., Reicher, S. and Wetherell, M.S. (Eds), Rediscovering the Social Group: A Self-Categorization Theory, Blackwell, Oxford, 42-67.

Verlegh, P. W. (2007). Home country bias in product evaluation: the complementary roles of economic and socio-psychological motives. Journal of International Business Studies, 38(3), 361-373.

Vietnamnet. (2014). Vietnamnetvn. Retrieved Sept, 2014, from http://english.vietnamnet.vn/fms/infocus/104409/overview-of-the-east-sea-dispute.html.

Wang, X. \& Yang, Z. (2008). Does country-of-origin matter in the relationship between brand personality and purchase intention in emerging economies?: Evidence from China's auto industry. International Marketing Review, 25(4), 458-474.

Witkowski, T. (2000). Effects of animosity toward China on willingness to buy Chinese products. Managing in a turbulent international business environment, 18, 470-7.

Wood, V. R. \& Darling, J. R. (1993). The marketing challenges of the newly independent republics: product competitiveness in global markets. Journal of International Marketing, 1(1), 77-102.

Wooten, D. B. \& Reed, A. (2004). Playing it safe: Susceptibility to normative influence and protective selfpresentation. Journal of Consumer Research, 31(3), 551-556. 